\title{
PENGARUH RETURN ON ASSET (ROA) DAN NET PROFIT MARGIN (NPM) TERHADAP HARGA SAHAM PADA PERUSAHAAN FARMASI TBK YANG TERDAFTAR DI BURSA EFEK INDONESIA
}

\author{
HJ. ERVIVA FARIANTIN \\ Sekolah Tinggi Ilmu Ekonomi AMM Mataram \\ e-mail :erviva65@gmail.com
}

\begin{abstract}
ABSTRAK
Penelitian bertujuan untuk menganalisis pengaruh Return On Asset (ROA) dan Net Profit Margin (NPM) secara parsial dan simultan terhadap harga saham dan pengaruh paling dominan antara Return OnAsset (ROA) dan Net Profit Margin (NPM) terhadap harga saham pada perusahaan Farmasi Tbk. yang terdaftar di Bursa Efek Indonesia Tahun 2012-2017.

Populasi dalam penelitian berjumlah 10 Perusahaan dengan teknik pengambilan sampel menggunakan purposive sampling sehingga jumlah sampel sebanyak 5 perusahaan. Kriteria dalam pengambilan sampel adalah semua perusahaan Farmasi, Tbk. yang menerbitkan laporan keuangan lengkap periode 2012 -2017. Hasil penelitian menunjukkan secara parsial semua variable independen (ROA dan NPM) berpengaruh terhadap harga saham, dan secara simultan variable independen (ROA dan NPM) juga berpengaruh terhadap harga saham.
\end{abstract}

Kata kunci : ROA, NPM, Harga saham

\section{ABSTRACT}

The research aims to analyze the influence of Return on Assets (ROA) and Net Profit Margin (NPM) partially and simultaneously on stock prices and the most dominant influence between Return On Asset (ROA) and Net Profit Margin (NPM) on stock prices in Pharmaceutical public companies listed on the Indonesia Stock Exchange in 2012-2017.

The population in the study amounted to 10 companies with the sampling technique using purposive sampling so that the number of samples is 5 companies. The criteria in sampling are all Pharmaceutical public companies which issued a complete financial report for the period 2012-2017. The results show partially all independent variables (ROA and NPM) have an effect on stock prices, and simultaneously the independent variables (ROA and NPM) also have an effect on stock prices

Keywords: ROA, NPM, Stock price

\section{PENDAHULUAN}

\section{Latar Belakang}

Dunia usaha dewasa ini dilihat secara kasat mata sangatlah cepat perkembangannya sehingga sangatlah perlu dibutuhkan konsep yang jelas yang harus direncanakan secara matang oleh pelakunya. Butuh inovasi yang berkelanjutan atas usaha yang dijalankan dan membutuhkan modal yang besar untuk meningkatkan kinerja suatu perusahaan sehingga tidak tertinggal jauh oleh para pesaingnya.

Apabila membutuhkan modal, maka perusahaan dapat memperolehnya dengan berbagai macam cara, salah satu diantaranya dapat terpenuhi melalui pihak ketiga atau investor. Investor sering melakukan transaksi investasi dengan tujuan untuk mendapatkan keuntungan dari perusahan yang diinvestasikannya, dan hal ini dapat terjadi bila dilakukan di Pasar modal, karena Pasar modal merupakan tempat untuk kegiatan yang berhubungan dengan penawaran umum dan perdagangan efek.

Perdagangan efek di Indonesia dapat dijumpai di Bursa Efek Indonesia atau BEI yang menawarkan berbagai ragam instrument seperti saham, obligasi, reksadana, waran dan derivative lainnya. Tujuan dari BEI 
adalah membantu masyarakat umum dalam berinvestasi dan sebagai sarana untuk memperoleh modal bagi perusahaan.

Perusahaan yang ingin memperoleh modal dari investor, maka harus dapat mendaftarkan ke BEIsebagai perusahaango public sehingga sahamnya dapat dibeli oleh para investor lainatau masyarakat yang memiliki dana lebih, yang dapat digunakandalam peningkatan kinerja perusahaan.

Kinerja perusahaan dapat dikatakan baik apabila perusahaan dapat menghasilkan keuntungan (Capital Gain) bagi para pemilik saham yang selanjutnya akan dibayarkan kepada para investor dalam bentuk dividen. Selain itu kinerja perusahaan dikatakan baik apabila mampu meningkatkan permintaan akan sahamnya.

Harga saham merupakan salah satu indikator untuk mengukur keberhasilan pengelolaan perusahaan. Pemegang saham yang tidak puas terhadap kinerja manajemen dapat menjual saham yang dimiliki dan menginvestasikan uanganya ke perusahaan lain. Jika hal ini dilakukan, maka akan menurunkan harga saham suatu perusahaan. Jika semakin tinggi harga saham, maka semakin tinggi nilai perusahaan tersebut, begitu pulasebaliknya. Harga saham yang terlalu rendah sering diartikan sebagai kinerja keuangan perusahaan yang kurang baik, sehingga para investor akan mempertimbangkan untuk berinvestasi.

Sebelum melakukan pembelian dan penjualan saham, para investor selalu melakukan analisis terlebih dahulu untuk mengetahui apakah saham yang akan dibeli dapat memberikan keuntungan atau justru akan memberikan kerugian. Ada beberapa pendekatan atau alat analisis yang digunakan yaitu analisis tekhnikal dan analisis fundamental.

Dalam penelitian ini akan digunakan pendekatan analisis fundamental, karena analisis fundamental dapat memberikan informasi mengenai kondisi kinerja keuangan perusahaan, yang berdampak pada laba yang dihasilkan oleh perusahaan. Analisis fundamental merupakan pendekatan untuk menghitung nilai intrinstik saham biasa (common stock) dengan menggunakan data keuangan perusahaan (Egi,2014:24).

Data keuangan perusahaan dapat dilihat melalui laporan keuangan, sehingga investor dapat mengetahui besar kecilnya nilai rasio yang dapat mempengaruhi harga saham perusahaan, dan selanjutnya investor dapat memaksimalkan keuntungan yang diinginkan.

Rasio-rasio yang dipertimbangkan oleh para investor sangatlah beragam tergantung keinginan para investor itu sendiri. Dalam penelitian ini akan dilihat dari sudut pandang Retrun On Asset (ROA), Net Profit Margin (NPM).

Menurut Suharno(2016:8) Return On Asset (ROA) mengukur seberapa baik manajemen menggunakan semua aktiva untuk menghasilkan keuntungan atau laba. Rasio ini menggabungkan antara laba sebelum pajak dengan total aktiva. Dengan ROA yang semakin tinggi maka return yang dihasilkan oleh suatu perusahaan juga semakin tinggi sehingga harga saham perusahaan semakin tinggi, maka resiko yang ditimbulkan semakin kecil.

Net Profit Margin (NPM) merupakan rasio pendapatan terhadap penjualan. Joel G.. Siegel dan Jae K.Shim dalam buku Irham (2014:82)mengatakan " Margin laba bersih sama dengan laba bersih dibagi dengan penjualan bersih, dan margin laba kotor sama dengan laba kotor dibagi laba bersih". Semakin tinggi margin laba menunjukan perusahaan mendapatkan hasil yang baik yang melebihi harga pokok penjualan.

Turun naiknya harga saham perusahaan akan mempengaruhi keputusan investor untuk berinvestasi di perusahaan yang go public. Berikut ini gambaran tentang pergerakan harga saham perusahaan Farmasi yang terdaftar di BEI selama tahun 2012 - 2017 pada Tabel 1

Tabel 1.Daftar Harga Saham Perusahaan Farmasi Tbk. Tahun 2012-2017

\begin{tabular}{|l|l|l|l|l|l|l|l|}
\hline \multirow{2}{*}{ No. } & \multirow{2}{*}{ Kode Perusahaan } & \multicolumn{6}{|c|}{ Harga Saham (Rp) Tahun } \\
\cline { 3 - 8 } & & 2012 & 2013 & 2014 & 2015 & 2016 & 2017 \\
\hline 1. & SIDO & - & 700 & 610 & 550 & 520 & 545 \\
\hline 2. & KAEF & 740 & 590 & 1.465 & 870 & 2.750 & 2.700 \\
\hline 3. & KLBF & 1.060 & 1.250 & 1.830 & 1.320 & 1.515 & 1.690 \\
\hline 4. & TSPC & 3.725 & 3.250 & 2.864 & 1.750 & 1.970 & 1.800 \\
\hline 5. & DVLA & 1.650 & 2.200 & 1.690 & 1.300 & 1.755 & 1.960 \\
\hline 6. & INAF & 330 & 153 & 355 & 168 & 4.680 & 5.900 \\
\hline 7. & MERK & 147.000 & 152.000 & - & 145.000 & 9.200 & 8.500 \\
\hline 8. & PYFA & 177 & 147 & 135 & 112 & 200 & 183 \\
\hline 9. & SQBB & 238.000 & 304.000 & 315.000 & 338.000 & 413.500 & - \\
\hline 10. & SCPI & 28.000 & - & - & - & - & - \\
\hline
\end{tabular}


Data di atas menunjukan bahwa harga saham perusahaan Farmasi dari tahun ke tahun mengalami fluktuasi. Menurut Suharno (2016) yang meneliti tentang pengaruh rasio keuangan terhadap harga saham pada perusahaan Farmasi yang terdaftar di BEI tahun 2011-2014, ROA berpengaruh signifikan terhadap harga saham. Menurut Lidya (2015) tentang pengaruh ROA, ROE dan NPM terhadap harga saham perusahaan Manufaktur periode 2010-2013, menunjukan hasil penelitian yang berbeda dengan Suharno, bahwa ROA tidak berpengaruh signifikan terhadap harga saham.

Lili dan Bambang (2017) tentang pengaruh EPS dan NPM terhadap harga saham pada perusahaan Properti. Hasil penelitian menunjukan bahwa EPS dan NPM berpengaruh signifikan terhadap harga saham.

\section{Rumusan Masalah}

1. Apakah Return On Asset (ROA) dan Net Profit Margin (NPM) berpengaruh secara parsial dan simultan terhadap harga saham pada perusahaan Farmasi Tbk. yang terdaftar di Bursa Efek Indonesia Tahun 2012-2017?

2. Manakah yang berpengaruh paling Dominan antara Return OnAsset (ROA) dan Net Profit Margin (NPM) terhadap harga haham pada perusahaan Farmasi Tbk. yang terdaftar di Bursa Efek Indonesia Tahun 2012-2017?

\section{Tujuan Penelitian}

Tujuan dari penelitian ini adalah untuk menganalisis pengaruh Return On Asset (ROA) dan Net Profit Margin (NPM) secara parsial dan simultan terhadap harga saham dan pengaruh paling dominan antara Return OnAsset (ROA) dan Net Profit Margin (NPM) terhadap harga saham pada perusahaan Farmasi Tbk. yang terdaftar di Bursa Efek Indonesia Tahun 2012-2017?

\section{Hipotesis}

H1: Diduga ROA dan NPM Berpengaruh Signifikan terhadap Harga Saham secara Parsial H2 : Diduga ROA dan NPM Berpengaruh Signifikan Terhadap Harga Saham Secara Simultan H3 : Diduga ROA Berpengaruh Paling Dominan Terhadap Harga Saham

\section{METODE PENELITIAN}

\section{Jenis Penelitian}

Jenis penelitian yang digunakan adalah penelitian asosiatif. Menurut Sugiyono (2013:57) penelitian asosiatif adalah penelitan yang bertujuan untuk mengetahui hubungan antara dua variabel atau lebih.

\section{Teknik Pengumpulan Data}

Teknik pengumpulan data yang digunakan adalah teknik dokumentasi, yaitu mengumpulkan data-data dari laporan keuangan perusahaan farmasi yang terdaftar di Bursa Efek Indonesia periode 2012-2017.

\section{Populasi, Sampel dan Teknik Pengambilan Sampel}

Populasi dalam penelitian ini adalah Perusahaan Farmasi yang terdaftar di Bursa Efek Indonesia Tahun 2012-2017, berjumlah 10 (sepuluh) perusahaan. Dari 10 perusahan ditentukan 5 (lima) perusahaan secara purposive sampling, dengan pertimbangan kriteria-kriteria tertentu, yaitu

perusahaan yang mempublikasikan laporan keuangan lengkap periode 2012-2017 dan perusahaan yang memperoleh laba selama periode 2012-2017.

\section{Jenis dan Sumber Data}

Jenis data yang digunakan adalah data kuantitatif, merupakan data yang berbentuk angka dan dapat dihitung, seperti laporan keuangan yang terdiri dari neraca dan laporan laba rugi perusahaan farmasi yang 
terdaftar di BEI dari tahun 2012-2017, yang bersumber pada laporan historis rasio-rasio keuangan perusahaan Farmasi yang terdaftar di BEI periode 2012-2017.

\section{Teknik Analisis Data}

Adapun teknik analisis data yang digunakan dalam penelitian ini terdiri dari :

\section{Uji Asumsi Klasik}

\section{a. Uji Normalitas}

Bertujuan untuk menguji apakah dalam model regresi, variabel penganggu atau residu memiliki distribusi normal dengan menggunakan analisis grafik normal plot.

\section{b. Uji Multikolinieritas}

Uji multikolinearitas bertujuan untuk menguji apakah model regresi ditentukan adanya korelasi antara variabel bebas atau independen. Model regresi yang baik seharusnya tidak terjadi korelasi di antara variabel independen. Untuk mengetahui ada atau tidaknya multikolinearitas di dalam model regresi adalah sebagai berikut (Imam,2016:103-104) :

-Adanya multikolinearitas, jika nilai Tolerance $\leq 0,10$ atau nilai varian inflation factory (VIF) $\geq 10$.

-Tidak adanya multikolinearitas, jika nilai Tolerance $\geq 0,10$ atau nilai VIF $\leq 10$.

\section{c. Uji Autokorelasi}

Uji autokorelasi bertujuan menguji apakah dalam model regresi linier ada korelasi antara kesalahan pengganggu pada periode $t$ dengan kesalahan pengganggu pada periode $t-1$. Pengambilan keputusan ada tidaknya autokorelasi sebagai berikut (Ghozali,2016:108):

- Tidak ada autokorelasi positif jika $\mathrm{dl} \leq \mathrm{d} \leq \mathrm{du}$

- Tidak ada korelasi negatif jika $4-\mathrm{dl}<\mathrm{d}<4$ atau $4-\mathrm{du} \leq \mathrm{d} \leq 4-\mathrm{dl}$

- Tidak ada autokorelasi, positif atau negatif jika $\mathrm{du} \leq \mathrm{d} \leq 4-\mathrm{du}$

\section{d. Uji Heteroskedastisitas}

Uji heteroskedastisitas bertujuan untuk menguji apakah dalam model regresi terjadi ketidaksamaan variance dari residual satu pengamatan ke pengamatan yang lain. Model regresi yang baik adalah yang Homoskedastisitas atau tidak terjadi Heteroskedastisitas. Deteksi ada tidaknya heteroskedastisitas dapat dilihat dari ada pola seperti titik-titik yang membentuk pola tertentu yang teratur (bergelombang, melebar kemudian menyempit), maka mengindikasikan telah terjadi heteroskedastisitas.

Uji glejser mengusulkan untuk meregresi nilai absolut residual terhadap variabel independen. Jika nilai signifikansi lebih besar dari 5\% atau signifikansi $>0,05$ maka model regresi tidak terjadi heteroskedastisitas, sebaliknya jika nilai signigikansi $<0,05$ maka model regresi terjadi heteroskedastisitas.

\section{Regresi Linier Berganda}

Regresi linier berganda bertujuan untuk menguji pengaruh dari dua atau lebih variabel bebas terhadap variabel terikat yang diketahui melalui persamaan regresinya(Sugiyono,2015:275).

Persamaan Regresi Linier Berganda adalah sebagai berikut

$$
Y=\alpha+\beta_{1} X_{1}+\beta_{2} X_{2}+\beta_{3} X_{3}+\beta_{4} X_{4}+e
$$

\section{Keterangan :}

$\mathrm{Y}=$ Harga Saham, $\mathrm{A}=$ Konstanta, $\beta_{1 \ldots} \beta_{2}=$ Koefisien Regresi, $\mathrm{X}_{1}=$ Return On Asset $(\mathrm{ROA})$,

$\mathrm{X}_{2}=$ Net Profit Margin $(\mathrm{NPM}), \mathrm{e}=$ Kesalahan Residu

\section{Uji Hipotesis}

\section{a.Uji t (Parsial)}

Uji t dilakukan untuk menguji pengaruh signifikansi dari masing-masing variabel independen (ROA dan NPM) terhadap variabel dependen (harga saham) secara individu, dilakukan melalui pengujian terhadap koefisien regresi dengan cara melakukan uji t yaitu membandingkan antara $t$ table dengan $t$ hitung. 


\section{b.Uji F (Simultan)}

Uji F dilakukan untuk mengetahui ada tidaknya pengaruh secara bersama-sama variabel independen terhadap variabel dependen dengan cara membandingkan nilai $\mathrm{F}$ hasil perhitungan dengan nilai $\mathrm{F}$ menurut tabel. Bila nilai $\mathrm{F}$ hitung lebih besar dari F tabel, maka H0 ditolak dan menerima HA.

\section{c.Uji Koefisien Determinasi $\left(R^{2}\right)$}

Koefisien determinasi $\left(\mathrm{R}^{2}\right)$ berguna untuk mengukur seberapa jauh kemampuan model dalam menerangkan variasi variabel dependen. Nilai $R^{2}$ yang mendekati satu berarti variabel independennya memberikan hampir semua informasi yang dibutuhkan untuk memprediksi variasi variabel dependen.

\section{d. Uji $\beta$ (Koefisien Beta)}

Uji dominan digunakan untuk mengetahui variabel mana yang paling dominan berpengaruh terhadap variabel terikat untuk mengetahui variabel bebas yang paling dominan, maka digunakan koefisen beta.

\section{HASIL DAN PEMBAHASAN}

\section{A. Hasil Penelitian}

\section{Deskripsi Data}

a. Return On Asset (ROA)

Berikut ini data Return On Asset (ROA) perusahaan farmasi yang terdaftar di BEI, sebagai sampel pada periode 2012-2017.

Tabel 2. Nilai ROA Perusahaan Farmasi Tbk. Periode 2012-2017

\begin{tabular}{|c|c|c|c|c|c|c|c|c|}
\hline \multirow{2}{*}{ Perusahaan } & \multirow{2}{*}{$\begin{array}{c}\text { Kode } \\
\text { Saham }\end{array}$} & \multicolumn{6}{|c|}{$\operatorname{ROA}(\%)$} & \multirow{2}{*}{$\begin{array}{c}\text { Rata- } \\
\text { rata }\end{array}$} \\
\hline & & 2012 & 2013 & 2014 & 2015 & 2016 & 2017 & \\
\hline PT. Kimia Farma Tbk & KAEF & 9,88 & 8,68 & 7,90 & 7,69 & 5,80 & 5,36 & 7,55 \\
\hline PT. Kalbe Farma Tbk & KLBF & 18,41 & 16,96 & 16,62 & 14,63 & 15,10 & 14,47 & 16,03 \\
\hline PT. Tempo Scan Pacific Tbk & TSPC & 12,17 & 11,06 & 10,11 & 8,70 & 7,01 & 7,31 & 9,39 \\
\hline PT.Darya-V.Laboratoria Tbk & DVLA & 13,86 & 10,57 & 6,55 & 7,84 & 9,93 & 9,90 & 9,78 \\
\hline PT. Indofarma Tbk & INAF & 1,73 & $-4,80$ & $-2,71$ & $-2,36$ & $-2,05$ & $-3,02$ & $-2,20$ \\
\hline Rata-rata & & 11,21 & 8,49 & 7,69 & 7,30 & 7,16 & 6,80 & 8,11 \\
\hline
\end{tabular}

\section{b.Net Profit Margin (NPM)}

NPM merupakan pendapatan bersih dibandingkan dengan penjualan, semakin tinggi NPM maka semakin baik operasi suatu perusahaan. Berikut ini nilai NPM perusahaan farmasi sebagai sampel pada periode 2012-2017.

Tabel 3.Nilai NPM Perusahaan Farmasi Tbk. Periode 2012-2017

\begin{tabular}{|l|l|r|r|r|r|r|r|r|}
\hline \multirow{2}{*}{ Perusahaan } & \multirow{2}{*}{$\begin{array}{c}\text { Kode } \\
\text { Saham }\end{array}$} & \multicolumn{6}{|c|}{ NPM (\%) } & \multirow{2}{*}{$\begin{array}{c}\text { Rata- } \\
\text { rata }\end{array}$} \\
\cline { 3 - 9 } & & $\mathbf{2 0 1 2}$ & $\mathbf{2 0 1 3}$ & $\mathbf{2 0 1 4}$ & $\mathbf{2 0 1 5}$ & $\mathbf{2 0 1 6}$ & $\mathbf{2 0 1 7}$ & \\
\hline PT. Kimia Farma Tbk & KAEF & 5,49 & 4,93 & 5,19 & 5,46 & 4,67 & 5,41 & 5,19 \\
\hline PT. Kalbe Farma Tbk & KLBF & 12,72 & 12,00 & 11,89 & 11,20 & 11,87 & 11,91 & 11,93 \\
\hline PT. Tempo Scan Pacific Tbk & TSPC & 9,47 & 9,26 & 7,73 & 6,38 & 5,87 & 6,00 & 7,45 \\
\hline PT. Darya-V. Laboratoria Tbk & DVLA & 13,70 & 11,40 & 7,30 & 8,30 & 10,50 & 10,30 & 10,25 \\
\hline PT. Indofarma Tbk & INAF & 3,66 & $-4,05$ & 0,08 & 0,40 & $-1,04$ & $-2,84$ & $-0,63$ \\
\hline Rata-rata & & $\mathbf{9 , 0 1}$ & $\mathbf{6 , 7 1}$ & $\mathbf{6 , 4 4}$ & $\mathbf{6 , 3 5}$ & $\mathbf{6 , 3 7}$ & $\mathbf{6 , 1 6}$ & $\mathbf{6 , 8 4}$ \\
\hline
\end{tabular}




\section{c.Harga Saham}

Harga saham di bursa efek ditentukan berdasarkan permintaan dan penawaran atau kekuatan tawarmenawar yang dilakukan oleh para investor di bursa. Semakin banyak orang yang ingin membeli saham, maka harga saham tersebut akan bergerak naik. Berikut ini disajikan nilai harga saham perusahaan farmasi sebagai sampel dalam periode 2012-2017.

Tabel 4. Nilai Harga Saham Perusahaan Farmasi Tbk. Periode 2012-2017

\begin{tabular}{|c|c|c|c|c|c|c|c|c|}
\hline \multirow{2}{*}{ Perusahaan } & \multirow{2}{*}{$\begin{array}{c}\text { Kode } \\
\text { Saham } \\
\end{array}$} & \multicolumn{6}{|c|}{ Harga Saham } & \multirow{2}{*}{$\begin{array}{c}\text { Rata- } \\
\text { rata }\end{array}$} \\
\hline & & 2012 & 2013 & 2014 & 2015 & 2016 & 2017 & \\
\hline PT. Kimia Farma Tbk & KAEF & 740 & 590 & 1465 & 870 & 2750 & 2700 & 1519,167 \\
\hline PT. Kalbe Farma Tbk & KLBF & 1060 & 1250 & 1830 & 1320 & 1515 & 1690 & 1444,167 \\
\hline PT. Tempo Scan Pacific Tbk & TSPC & 3725 & 3250 & 2864 & 1750 & 1970 & 1800 & 2559,833 \\
\hline 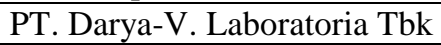 & DVLA & 1650 & 2200 & 1690 & 1300 & 1755 & 1960 & 1759,167 \\
\hline PT. Indofarma Tbk & INAF & 330 & 153 & 355 & 168 & 4680 & 5900 & 1931 \\
\hline & & & 1488,6 & 1640,8 & 1081,6 & 2534 & 2810 & 1842,667 \\
\hline
\end{tabular}

\section{Analisis Data}

\section{Hasil Uji Asumsi Klasik}

\section{a.Uji Normalitas}

Hasil Uji normalitas dengan menggunakan Metode Grafik dapat dijelaskan bahwa titik-titik data meyebar disekitar garis diagonal, serta penyebarannya mengikuti arah garis diagonal. Maka model regresi dalam penelitian ini memenuhi syarat asumsi normalitas.

\section{b.Uji Multikolinearitas}

Hasil uji multikolinearitas dapat digambarkan bahwa nilaitoleranceuntuk ROA dan NPM lebih besar dari pada 0,10 atau nilai tolerance $\geq 0,10$ yaitu nilai toleranceROA sebesar 0,117 dan NPM sebesar 0,187 . Untuk nilai VIF ROA dan NPM lebih kecil dari 10 atau nilai VIF $\leq 10$ yaitu nilai VIF ROA sebesar 8,334 dan VIF NPM sebesar 6,334 ini menunjukan bahwa ROA dan NPM tidak adanya multikolinearitas.

\section{c.Uji Autokorelasi}

Pengambilan keputusan ada tidaknya autokorelasi dilakukan dengan uji Durbin Watson (uji DW). Hasil pengujian mengambarkan bahwa angka $D-W$ sebesar 2,014. Dari tabel Durbin-Watson, untuk $n=30, k=3$ diperoleh $\mathrm{dl}=1,143$ dan $\mathrm{du}=1,739$ sehingga $4-\mathrm{dl}=2,857$ dan $4-\mathrm{du}=2,261$, maka $\mathrm{du} \leq \mathrm{d} \leq 4-\mathrm{du}$ atau $1,739 \leq$ $2,088 \leq 2,261$. Oleh karena nilai DW lebih besar dari batas atas du $(1,739)$ dan kurang dari 4-du $(2,261)$, maka pada model regresi tidak ada autokorelasi positif atau negatif, atau dapat disimpulkan tidak terdapat autokorelasi.

\section{d.Uji Heteroskedastisitas}

Untuk mendeteksi ada atau tidaknya heteroskedastisitas, digunakan grafik plot dan uji glejser. Hal ini dapat digambarkan ada pola seperti titik-titik yang membentuk pola tertentu yang teratur (bergelombang, melebar kemudian menyempit), maka mengindikasikan telah terjadi heteroskedastisitas. Uji glejser, bila nilai signifikansi lebih besar dari 5\% atau signifikansi > 0,05 maka model regresi tidak terjadi heteroskedastisitas.

\section{Analisis Regresi Linear Berganda}

Berikut ini hasil uji Regresi Linear Berganda dapat dilihat pada Tabel 5 berikut ini. 
Coefficients(a)

Tabel 5.Hasil Uji Regresi Berganda

\begin{tabular}{|rl|r|r|r|r|r|}
\hline \multirow{2}{*}{ Model } & \multicolumn{2}{|c|}{$\begin{array}{c}\text { Unstandardized } \\
\text { Coefficients }\end{array}$} & $\begin{array}{c}\text { Standardized } \\
\text { Coefficients }\end{array}$ & $\mathrm{t}$ & Sig. \\
\hline & & \multicolumn{1}{|c|}{ B } & Std. Error & Beta & & \\
\hline 1 & (Constant) & 2043.623 & 435.549 & & 4.692 & .000 \\
& ROA & 14.799 & 126.646 & .072 & 2.117 & .008 \\
& NPM & 46.935 & 167.355 & .173 & 3.280 & .001 \\
\hline
\end{tabular}

a Dependent Variable: HARGA_SAHAM

Dari Tabel 5. didapat persamaan regresi linear berganda sebagai berikut :

$$
\begin{array}{r}
\mathbf{Y}=\boldsymbol{\alpha}+\boldsymbol{\beta}_{\mathbf{1}} \mathbf{X}_{\mathbf{1}}+\boldsymbol{\beta}_{\mathbf{2}} \mathbf{X}_{\mathbf{2}}+\mathbf{e} \\
\mathrm{HS}=2043,623+14,799 \mathrm{ROA}+46,935 \mathrm{NPM}+\mathrm{e}
\end{array}
$$

\section{Hasil Pengujian Hipotesis}

\section{Hasil Uji t(Parsial)}

Tabel 6. Hasil Uji t (Parsial)

Coefficients(a)

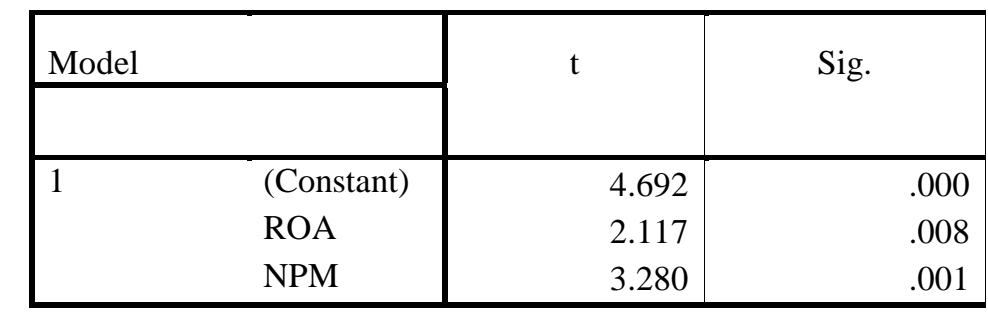

a Dependent Variable: HARGA_SAHAM

Nilai t tabel sebesar 2,056

Dari Tabel 6 digambarkan bahwa secara parsial masing-masing variabel independen terhadap variabel dependen adalah :variabel ROA memiliki t hitung sebesar 2,117. Hasil penelitian diperoleh nilai $\mathrm{t}$ hitung $>\mathrm{t}$ tabel yaitu 2,117> 2,056 dan nilai signifikansi sebesar 0,008<0,05 maka variabel "ROA berpengaruh signifikan secara parsial terhadap harga saham". Variabel NPM memiliiki t hitung sebesar 3,280 dan nilai signifikansi sebesar 0,001. Dari penelitian diperoleh nilai $t$ hitung $>t$ tabel yaitu3,280 > 2,056 dan nilai signifikansi 0,001 <0,05 maka variabel "NPM berpengaruh signifikan secara parsial terhadap harga saham ".

\section{Uji F(Simultan)}

Tabel 7. Hasil Pengujian F(Simultan)

\begin{tabular}{|ll|l|ll|}
\hline & & & \\
Model & & F & Sig. \\
\hline 1 & $\begin{array}{l}\text { Regression } \\
\text { Residual } \\
\text { Total }\end{array}$ & 47.266 & & \\
& & & & \\
\hline
\end{tabular}

a Predictors: (Constant), NPM, ROA

b Dependent Variable: HARGA_SAHAM

Berdasarkan Tabel 7 hasil uji $\mathrm{F}$ menujukan bahwa nilai $\mathrm{F}$ hitung> dari $\mathrm{F}$ tabel maka berarti berpengaruh signifikan secara simultan. Hasil uji $\mathrm{F}$ hitung sebesar 47,266 sedangkan nilai $\mathrm{F}$ tabel (k;n-k-1), (2;30-21=27), F tabel sebesar 3,354 Sehingga nilai $F$ hitung > F tabel atau 47,266> 3,354 jadi secara simultan variabel independen yaitu ROA dan NPM berpengaruh terhadap harga saham. 


\section{Uji Koefisien Determinasi $\left(R^{2}\right)$}

Pengujian ini dilakukan untuk mengetahui besarnya pengaruh variabel independen (ROA, NPM) dalam bentuk persentase. Berikut ini hasil uji Koefisien Determinasi R $^{2}$ :

Tabel 8. Hasil Pengujian Koefisien Determinasi $\left(\mathrm{R}^{2}\right)$

Model Summary(b)

\begin{tabular}{|l|c|c|c|c|}
\hline Model & $\mathrm{R}$ & R Square & $\begin{array}{c}\text { Adjusted R } \\
\text { Square }\end{array}$ & $\begin{array}{c}\text { Std. Error of } \\
\text { the Estimate }\end{array}$ \\
\hline 1 & $.707(\mathrm{a})$ & .711 & .662 & 1333.59532 \\
\hline
\end{tabular}
a Predictors: (Constant), NPM, ROA
b Dependent Variable: HARGA_SAHAM

Berdasarkan Tabel 8 di atas diperoleh nilai koefisien determinasi ( $R$ Square) sebesar 0,711 atau sama dengan $71,1 \%$. Hal ini menunjukkan bahwa sebesar $71.1 \%$ variabel harga saham dapat dijelaskan oleh variasi dari variabel independen yaitu ROA dan NPM, sedangkan 28,9\% dijelaskan oleh variabel lain.

\section{Uji $\beta$ (Koefisien Beta)}

Pengujian ini dilakukan untuk mengetahui diantara variable independen mana yang dianggap paling dominan berpengaruh terhadap variabel terikat.Berikut ini adalah hasil uji koefisien Beta $(\beta)$ :

Tabel 9. Hasil Pengujian Uji $\beta$ (Koefisien Beta)

Coefficients(a)

\begin{tabular}{|ll|l|}
\hline Model & \multicolumn{2}{|c|}{$\begin{array}{c}\text { Standardized } \\
\text { Coefficients }\end{array}$} \\
\hline & & \multicolumn{2}{|c|}{ Beta } \\
\hline 1 & (Constant) & \\
& ROA & .072 \\
& NPM & .173 \\
\hline
\end{tabular}

a Dependent Variable: HARGA_SAHAM

Berdasarkan Tabel 9 diperoleh hasil koefisien beta (Standardized Coefficients Beta) yang nilainya paling besar merupakan variabel NPM yaitu sebesar 0,173 Hal ini berarti nilai koefisien beta dari variabel NPM memiliki pengaruh paling dominan atau paling besar terhadap harga saham.

\section{B.Pembahasan}

\section{Pengaruh Return On Asset (ROA) Terhadap Harga Saham}

Secara parsial variabel ROA menunjukkan angka sebesar 2,117 dengan signifikansi sebesar 0,733 yang lebih besar dari 5\%. Jadi hipotesis dalam penelitian ini yang menyatakan bahwa ROA berpengaruh signifikan secara parsial terhadap harga saham adalah dapat diterima.

ROA merupakan rasio profitabilitas yang digunakan untuk mengukur efektifitas perusahaan dalam menghasilkan keuntungan dengan melihat aset yang dimiliki oleh perusahaan, sehingga para investor dapat mempertimbangkan keputusan berinvestasi dengan melihat dari kondisi besar-kecilnya nilai ROA. Hasil penelitian ini sesuai dengan penelitian yang dilakukan oleh Suharno (2011) yang mengatakan bahwa ROA berpengaruh signifikan terhadap harga saham.

\section{Pengaruh Net Profit Margin (NPM) Terhadap Harga Saham}

Secara parsial variabel NPM memiliki nilai regresi 3,280 dan nilai signifikansi sebesar 0,001 yang lebih kecil dari 5\%. Jadi hipotesis dalam penelitian ini, NPM berpengaruh signifikan terhadap harga saham adalah dapat diterima.

NPM merupakan keuntungan dengan membandingkan laba setelah bunga dan pajak dengan penjualan. NPM yang tinggi berarti operasi suatu perusahaan baik, karena laba bersih yang diperoleh melebihi nilai penjualan, tetapi rasio ini tidak menggambarkan besarnya persentase keuntungan bersih yang diperoleh 
perusahaan karena adanya unsur pendapatan dan biaya operasional, sehingga investor kurang mengetahui prospek kedepan perusahaan yang akan dinvestasikan. Hasil penelitian ini sama dengan hasil penelitian Achmad (2012) yang menyatakan NPM berpengaruh negatif terhadap harga saham.

\section{Pengaruh ROA dan NPM Secara Simultan Terhadap Harga Saham}

Hasil uji F menunjukkan bahwa hasil $\mathrm{F}$ hitung sebesar 47,266 dengan tingkat signifikansi 0,000 yang lebih kecil dari 5\%, hal ini berarti secara simultan variabel ROA dan NPM berpengaruh signifikan terhadap harga saham. Harga saham merupakan penilaian baik atau buruknya suatu perusahaan, hal tersebut dikarenakan semakin banyak orang yang membeli, maka harga saham tersebut akan bergerak naik dan sebaliknya bila banyak yang menjual saham maka harga saham akan bergerak turun akibat dari aksi yang dilakukan oleh investor. Perusahaan yang baik untuk diinvestasikan dapat dilihat dari segi fundamentalnya. Fundamental perusahaan dapat dilihat pada laporan keuangan yang sudah dipublikasikan. Di dalam laporan keuangan terdapat rasio yang melambangkan kondisi fundamental perusahaan tersebut baik. Perusahaan yang memperoleh rasio yang terdiri dari ROA dan NPM yang baik cendrung mempunyai tingkat harga saham yang baik dan ini merupakan tolak ukur bagi para investor untuk melakukan investasi pada perusahaan tersebut. Setiap investasi yang dilakukan oleh investor, mengharapkan mendapatkan return yang tinggi. Hal ini sesuai dengan hasil penelitian yang dilakukan oleh Tri (2017) yang mengatakan adanya pengaruh signifikan antara variabel ROA dan NPM secara simultan terhadap harga saham.

\section{Pengaruh Paling Dominan Terhadap Harga Saham}

Hasil uji Beta menunjukkan bahwa yang paling dominan adalah variable NPM dengan hasil sebesar 0,173. NPM merupakan keuntungan yang diperoleh dari membandingkan antara laba setelah bunga dan pajak dengan penjualan, sehingga investor perlu mengetahui berapa nilai bersih dari keuntungan yang didapatkan oleh perusahaan yang nantinya akan dibagi kepada para investor yang telah menanamkan modalnya di perusahaan, selain itu NPM yang tinggi mencerminkan hasil operasi suatu perusahaan yang baik, karena laba bersih yang diperoleh ternyata melebihi nilai penjualan, Dengan demikian para investor harus paham dan jeli dalam menginvestasikan dananya di perusahaan pencari dana.

Hasil penelitian ini ternyata sama dengan hasil penelitian yang dilakukan oleh Tri (2017) yang mengatakan bahwa NPM berpengaruh paling dominan terhadap harga saham.

\section{SIMPULAN DAN SARAN}

\section{Simpulan}

Dari hasil penelitian dapat disimpulkan sebagai berikut

1. Variabel ROA dan NPM berpengaruh signifikan terhadap harga saham.

- Secara parsialReturn on asset (ROA) padaperusahaan Farmasi Tbk. dinyatakan berpengaruh terhadap harga saham karenacapaian nilai signifikansinya 0,008 lebih kecil dari standar taraf signifikan 0,05. Hal ini menggambakan bahwa secara umum perusahaanFarmasi, Tbk mampu menghasilkan keuntungan yang sangat efektif dengan melihat pada asset yang dimilikinya sehingga akan berdampak pada meningkatnya harga saham perusahaan Farmasi, Tbk.

- Secara parsialNet profit margin (NPM) pada perusahaan Farmasi Tbk. dinyatakan berpengaruh terhadap harga saham karena nilai signifikansinya 0,001 lebih kecil dari standar taraf signifikan 0,05. Hal ini menggambarkan bahwa secara umum perusahaan Farmasi, Tbk berhasil dalam mengelolah bisnisnya, dan mampu menetapkan harga produknya dengan benar serta mampu mengendalikan biaya dengan baik.

- Secara simultan ROA dan NPMpada perusahaan Farmasi Tbk. dinyatakan berpengaruh signifikan terhadap harga saham karena tingkat signifikansinya 0,000 lebih kecil dari 0,05. Harga saham merupakan penilaian tentang baik atau buruknya suatu perusahaan, karena semakin banyak orang yang membeli, maka harga saham tersebut akan bergerak naik.

2. NPM berpengaruh dominan terhadap harga saham, karena hasil Beta NPM ternyta lebih besar daripada ROA yaitu 0,173 >0,072. Net profit margin (NPM) menunjukkan proporsi penjualan yang tersisa setelah dikurangi semua biaya-biaya terkait. Bagi investor NPM biasanya digunakan untuk mengukur seberapa efisien manajemen mengelola perusahaannya, memperkirakan profitabilitasnyadimasa depan, dapat melihat besarnya persentase pendapatan yang digunakan untuk membayar biaya operasional dan biaya 
non operasional serta besarnya persentase tersisa untuk membayar dividen ke para pemegang saham ataupun berinvestasi kembali ke perusahaannya.

\section{Saran-saran}

Saran yang dapat disampaikan adalah sebagai berikut :

1. Kepada calon investor supaya lebih cermat menilai laporan keuangan dan alat analisis yang mendukung apabila ingin berinvestasi di Pasar modal.

2. Kepada pihak manajemen Perusahaan Farmasi Tbk. diharapkan hasil penelitian ini dapat dijadikan motivasi untuk meningkatkan kinerja manajemennya, sehingga dapat mempertahankan dan lebih lagi meningkatkan nilai rasio diatas standar.

\section{DAFTAR PUSTAKA}

Achmad, Husaini. 2012. Pengaruh Variabel Return On Assets, Return On Equity, Net Profit Margin Dan Earning Per Share Terhadap Harga Saham Perusahaan. Jurnal Profit, Volume 6, Nomor 1, Juni 2012.

Daniarto, Raharjo., Dul Muid. 2013. Analisis Pengaruh Faktor-Faktor Fundamental Rasio Keuangan Terhadap Perubahan Harga Saham. Ejournal-s1.undip.ac.id/index.php/accounting.

Egi Ferdianto. 2014. Analisis Pengaruh Return On Asset (ROA), Debt To Equity Ratio (DER), Net Profit Margin (NPM) dan Current Ratio (CR) Terhadap Harga Saham (Studi Pada Perusahaan Tambang yang Terdaftar di BEI Tahun 2011-2013). Universitas Islam Negeri Syarif Hidayatullah.

Imam, Ghozali. 2005. Aplikasi Analisis Multivariate dengan Program SPSS. Edisi Ketiga. Semarang: Universitas Diponegoro.

. 2013. Aplikasi Analisis Multivariate dengan Program SPSS. Cetakan IV. Semarang: Badan Penerbitan Universitas Diponegoro.

Kasmir. 2008. Analisis Laporan Keuangan. Raja Grafindo Persada. Jakarta

Lidya, Pratiwi Kesuma Ningdwi, 2015. Pengaruh ROA,ROE dan NPM Terhadap Harga Saham Pada Perusahaan Manufaktur Yang Terdaftar Di Bursa Efek Indonesia Tahun 2010-2013. Journal Administrasi Bisnis, 2017, 5 (2): 283-296. ejournal.adbisnis.fisip-unmul.ac.id

Samsul, M. (2015). Pasar Modal dan Manajemen Portofolio Edisi Kedua.:Erlangga. Jakarta

Suharno. 2016. Pengaruh Rasio Keuangan Terhadap Harga Saham Perusahaan Farmasi Yang Terdaftar Di Bursa Efek Indonesia Tahun 2010-2014. Skripsi S1. Universitas Negeri Yogyakarta, Yogyakarta.

Sugiyono. 2013. Metode Penelitian Pendidikan (Pendektan Kuantitatif, Kualitatif, dan R\&D). Alfabeta: Bandung. 2014. Metode Penelitian Bisnis Manajemen. Cetakan Kedua. Alfabeta. Bandung.

Tri, Nonik Sumaryanti. 2017.. Pengaruh ROA, EPS, NPM dan ROE Terhadap Harga Saham Perusahaan Sub Sektor Batu Bara Yang Terdaftar Di Bursa Efek Indonesia. eJournal Administrasi Bisnis.

Bursa Efek Indonesia (BEI). Laporan Keuangan dan Tahunan. (online). www.idx.co.id 